\title{
Cultivating Alternative Spaces - Zagreb's Community Gardens in Transition: From Socialist to Post-socialist Perspective
}

Lana Slavuj Borčić, Marin Cvitanović, Aleksandar Lukić

This paper is published in Geoforum 77, p. 51-60 (December 2016), http://dx.doi.org/10.1016/j.geoforum.2016.10.010

\begin{abstract}
This paper provides an in-depth analysis of community gardens in a (post)socialist setting during a time of key changes in their perception and management. Community gardens in Zagreb emerged in two specific economic and socio-cultural contexts and a diachronous approach to the study of urban gardens offers a unique insight into differences and similarities reflecting and contrasting those periods. Semistructured interviews and non- participatory observation were employed in the study. The results show that community gardens in Zagreb are multilayered places which satisfy diverse needs of the urban residents, including home grown food, socializing, recreation, contact with the nature, and even supplementation for low pensions. They can also be seen as examples of heterotopias or alternative spaces during both examined periods. In the socialist period they were secluded, private, pseudo-rural places in a semi-authoritarian, communal, and (supposedly) urban and industrial society. In post-socialist Zagreb, characterized by an uncontrolled and unplanned spatial context reliant on neoliberal market-oriented principles, social insensitivity and exclusion, the new gardens are depicted as beacons of communal involvement, grassroots movements, and the ability of citizens to stand together and make their voices heard.
\end{abstract}

Keywords: community gardens, socialism, post-socialism, Zagreb, activism 


\section{HIGHLIGHTS:}

- A diachronous approach to study of community gardens has been employed.

- The methodology consists of participatory observation and semistructured interviews.

- Gardens in socialism are seen as a continual of rural practices in an urban society.

- In post-socialism they are seen as an example of communal involvement.

- Visual characteristics of community gardens changes in two contrasting periods. 


\section{Introduction}

"What are the chances of urban residents leading lives different from what they were doomed to by this environment? Can they overcome what it prescribes them to be? Are there other opportunities hidden in the city of a different urban experience? 'Eizenberg E. (2013)

Community gardens have been a well-established practice in the city of Zagreb for quite a while now. Their beginnings can be traced to the increased influx of population during Zagreb's rapid industrialization in the late 1970s and 1980s and the building of new apartment blocks that accompanied it. Those first gardens started springing up spontaneously on unused land near the new buildings, a result of the new tenants' own initiative. Some plots that had been categorized as construction plots in urban plans weren't built upon right away, mostly due to lack of money. There was no official effort to landscape or to provide any other sort of content on them either (Gulin Zrnić 2012). These "alternative urbanizations" (Rihtman- Auguštin 1988) of public spaces were conducted outside of the official framework of the local authorities. The allotment garden model used in many other countries (e.g. Germany, Russia, Poland, Hungary, Slovakia) was nonexistent. Although a present and very visible mark in the urban landscape, these gardens were never officially recorded or included in spatial planning documents. As far as the local authorities were concerned, these gardens did not, and today still do not, officially exist. This partly changed in April 2013 when Zagreb's mayor Milan Bandić decided to establish the "Urban Gardens" project, mostly in different, new locations. This u-turn by the local authorities did not come without warning, it was preceded by months of lobbying conducted by numerous nongovernmental organizations who were trying to alert public and local authorities to the benefits the gardens provide to individuals and to the local community. The City decided to legalize this long-standing practice through the project by officially leasing land plots owned by the City to individuals demonstrating an interest in urban gardening. However, the old illegal gardens remained mostly outside the scope of this new project. The only difference was that they are now partly recorded and mapped.

As opposed to Croatian scientific literature, where the subject of community gardens is minimally researched, foreign literature abounds with research on this phenomenon. Community gardens have been discussed from many different perspectives and theoretical 
approaches which has revealed the multilayered nature of these spaces. So far they have been mostly praised for their positive outcomes in relation to the individual and society. Many studies have reported benefits including increased access to the following: open green spaces, fresh, safe and culturally appropriate food, job opportunities, education and training for youth and adults (Evers and Hodgson 2011; Crossney and Shellenberger 2012; Baker 2004; Wekerle 2004; Reynolds 2014; Schukoske 2000). Community gardens have been praised for their role in social capital building, neighbourhood revitalization, urban sustainability, alleviation of poverty, health promotion, and for their environmental benefits (Armstrong 2000; Firth et al 2011; Alaimo et al 2010; Turner 2011; Glover 2003, 2004; Glover et al 2005; Kingsley and Townsend 2006; Wakefield et al 2007; Dhakal and Lilith 2011; Kurtz 2001; Holland 2004; Ferris et al 2001; Stocker and Barnett 1998; Saldivar-Tanaka and Krasny 2004). Furthermore, urban gardens play an especially important role for food security in developing countries as urban agriculture appears to be associated with greater dietary diversity and calorie availability. Studies show that urban agriculture is predominantly an activity practiced by the poor households in developing countries. Having direct access to a wider variety of food via urban agriculture can help protect the poorest of urban citizens (Zezza and Tasciotti 2010; Moyo 2013; Ashebir et al 2007; Simatele and Binns 2008; Maxwell et al 1998). Additionally, community gardens are recognized as contested spaces and spaces of grassroots activism through which citizens can claim rights to their city (Schmelzkopf 1995; Schmelzkopf 2002; Staeheli et al 2002; Follmann and Viehoff 2014; Smith and Kurtz 2003; Eizenberg 2012a; Eizenberg 2012b; Lawson 2007) as well as a response to roll-back neoliberalism and the withdrawal of the local state apparatus from service provision (Rasol 2010; 2012). It is only recently that scholars shifted their attention from exclusively positive outcomes of urban agriculture to some of the negative aspects lurking under the surface. The Ghose and Pettygrove (2014) study on Milwaukee community gardens showed that citizen participation in the context of neoliberalization can simultaneously empower and challenge citizens. They argue that community gardens reinforce the neoliberal tenet that citizenship should be earned through active participation, which, in this case, is only accessible to individuals with the physical abilities, knowledge, and time to volunteer. Reynolds (2014) noticed that race-based and class-based disparities exist in New York's urban agriculture system. She found that farmers and gardeners experiences with obtaining financial resources varied widely in terms of the amount of funding and the strategies used to raise funds (community groups with white leaders reported raising larger amounts of funding than did groups led by people of color). The dominance of 
white people in community group leadership and alternative food movements are documented by other authors as well (Ghose and Pettygrove 2014; Meenar and Hoover 2012; Slocum 2006, 2007; Guthman 2008). Findings from all these studies remind us that community gardens are not isolated spaces, unconnected with their surroundings, rather multilayered sites which reflect, replicate and contest dominant social values and norms.

The research on community gardens differs vastly, not only based on the different approaches and perspectives, but also on the areas where it was conducted. Papers published in the USA, Canada, Australia and Western Europe, are the most numerous, at least among those written in English. A review of literature revealed that the research body on the development and characteristics of community gardens in Eastern Europe is less extensive. Studies conducted in former socialist countries often give us insight into the historical perspective of the development, and the attitudes and dominant social values assigned to the urban agriculture (e.g. in Poland, (Bellows 2004); in Russia (Moldakov 2000; Zavisca 2003; Boukharaeva and Marloie 2015). It is interesting to inspect the topic from this angle because of the vast and comprehensive socio-economic changes that followed the collapse of the socialist system. These full scale alterations mirror themselves in the vernacular landscapes of urban and peri-urban gardens. However, there are notable differences even within (post)socialist countries themselves. The Socialist Federative Republic of Yugoslavia, unlike the overwhelming majority of former socialist and communist countries in Europe, did not have any legal regulations pertaining to urban gardening. Urban gardens were created spontaneously, as individual actions, but also in response to certain social and political processes. With its specific economic development which differed significantly from countries of the former Soviet Sphere, the case of Yugoslavia demonstrates that (post)socialist countries have their own specific characteristics regarding urban agriculture that are worthy of our attention. Therefore, this study attempts to present experiences from community gardens in Zagreb. Zagreb was selected as a case study because in socialist Yugoslavia it was the largest and the most important industrial center of the whole country. Its development after the Second World War reflects best all the processes characteristic for Yugoslavia: rapid industrialization, a strong influx of people from rural areas, and large-scale expansion of apartment blocks throughout the city. Such processes in Zagreb were accompanied by the emergence of community gardens - tiny patches of cultivated land within the city's fabric.

Taking into consideration the broad-scale changes that occurred throughout Eastern Europe after the collapse of socialism and communism, this paper aims to provide insight into those community gardens from two perspectives. On one hand we wanted to record the 
experiences of those participating in their creation before the 1990s - during the times of socialism in Zagreb before the break-up of Yugoslavia and the major socio-economic changes that followed it. On the other hand we wanted to show the perspectives of the new gardeners who took up community gardening with the creation of the new urban gardens - in the scope of a neoliberal city undergoing transition. Additional information was gathered from representatives of local authorities directly involved in the creation of the "Urban Gardens" project in order to gain an insight into their view on the subject of community gardens. All aspects related to the gardens were studied from a "then-now" perspective in order to discover potential differences as well as similarities.

\section{Methodology}

The aim of this research was to produce a rich, in-depth description and understanding of the community gardens in Zagreb during a time of key changes in the perception and management of these areas. Our intent was to analyze the past and present of the gardens, i.e. to study the subject through a prism showing the past (before the 1990s) and the present (after 2013 and opening up the first gardens by the local authorities). In the period from the 1990s to 2013 there have been no considerable changes. The old gardens continued to exist (some were abandoned due to ageing of the gardeners, others were "inherited" from older gardeners) and the new gardens had yet to be established (in 2013). The pre-1991 period was a time of socialism, with Croatia being one of the six socialist republics of Yugoslavia. The social and economic circumstances of the time were vastly different from those after the 1990s. The transition from one socio-economic system to another has left its mark on both the space and the people. We believe that a diachronous approach to studying the gardens in Zagreb would reveal the differences as well as similarities reflecting and contrasting those two very different periods.

Qualitative methodology was employed in this research by using semi-structured interviews and non-participatory observation. The semi-structured interviews were conducted with twenty-six urban gardeners (12 respondents in old gardens on average over 60 years of age, and 14 in the new gardens with an average age of 45 (min 27 years, max over 60 years), activists from the Parkticipation and $3 \mathrm{~L}$ organizations ( $\mathrm{N}$ 2) which actively participated in actions to jump start the "Urban Gardens" project, and with representatives from the Department of Agriculture and Forestry of the City of Zagreb (N 2). Males and 
females were nearly equally represented in the interviews (M 14/ F 12). Thirty interviews were conducted during the second half of 2014, each lasting between 45 and 90 minutes. The questions in the interviews were related to who participates in community gardening, how gardens are started, maintained and organized, the gardeners' motives, and benefits of gardening. Respondents were not contacted in advance in both old and new gardens (except for the NGOs and City officials), rather they were approached in the gardens themselves. The gardeners were very open and there were no problems with gathering the desired information. The interviews were conducted in Croatian.

The terms old and new gardens are used extensively in this paper and warrant a detailed explanation. The old gardens are those created before the 1990s. Most of the gardeners we ran into in those gardens started gardening around 30 years ago, so they are mostly of older age (over 60 years old). The new gardens are those that were created by the "Urban Gardens" project, which started in 2013. All age categories were found to be present in the new gardens. The interviews were conducted in seven locations in the city: at the Sopot, Klara and Savica officially sanctioned community gardens and at the old illegal gardens in the Dubrava, Jarun and Prečko neighbourhoods. One of the Prečko gardens, the Ekoekipa Prečko Garden, was created after 2013 through the initiative of a number of active individuals who wanted a garden near their homes, despite the City being unable to provide the land at the desired location. Though this garden is not part of the officially sanctioned community gardens, it is more similar to them in most aspects than to the old gardens.

Due to the fact that the old gardens were never formally organized, and that they remain without any sort of formal representation, the individuals tending them could only be reached by directly visiting the gardens. Similarly, the new gardens have no formal representation. The people tending them have, however, started to group up spontaneously using on-line social networks with several more active individuals establishing themselves as informal representatives. This type of loose organization is not present in all the gardens some are more active organization-wise than others. The level of organization is one of the things setting the community gardens in Zagreb apart from those in other countries, like USA, Canada or Australia where organizations and some type of leadership are more often involved in community gardens (Smith and Kurtz 2003; Evers and Hodgson 2011; Baker 2004). In Zagreb, the new gardens are somewhat organized (initially by the City), but the old gardens have no organized management at all. 


\section{Old Community Gardens in Socialist Zagreb}

The period after World War II was a time of intense urbanization of Yugoslavia. This was a direct consequence of implementing an economic model which favored industrialization. Although the majority of the population was rural, little attention was given to the development of agricultural and rural areas (Pleskovic 1988). It was an allencompassing socio-economic movement comprising the deruralization and transformation of the country, and the transformation of the rural population into industrial workers (Seferagić 2006). Thus, the percentage of rural population in Yugoslavia decreased from $80 \%$ to $55 \%$ in less than 40 years (1947-1985). The sudden growth of cities was a result of push factors from the countryside like growing unemployment and lack of reform and pull factors from the cities which were not only economic, but also socio-cultural in part (Pleskovic 1988). These processes somewhat reflected the declared principles of the creation of new socialist cities: renouncing the market, removing the social differences between cities and the countryside, a more even distribution of industry and population, and the spatial integration of agriculture and industry (Musil 2005:27). The main focal point of industrialization in Yugoslavia, and its largest industrial centre, was Zagreb which reached its demographic peak during the socialist period. Even though this process achieved one of the main socio- economic political goals of the socialist government - the creation of a strong working class

- the deruralization of the society did not always result in deruralized individuals (Mišina 2013). Instead, the new socialist worker often had cultural roots firmly planted in the native rural setting, or as Mišina (2013) puts it, he was "stuck halfway between countryside and the city", trying to simultaneously reject and affirm his peasant and urban sides; the former being described as backwards and the latter modern and progressive.

This dichotomy can be seen in the emergence of illegal community gardens within the city of Zagreb, mostly during the 1970s and 1980s. After migrating to the city from rural areas or after construction developments forced the people to move from houses to apartment buildings, people continued their gardening practices in the new surroundings. For them this was a continuation of their traditional lifestyle that they brought with them to the city. None of the gardeners stated that they were forced to work in the gardens due to poverty or hunger, they were not the urban poor (unlike in some other examples, see Drake and Lawson 2014; Irvine et al 1999). 
These gardens can be considered as a typical example of alternative spaces, heterotopias, or spaces of otherness as Foucault imagined back in the 1960s (Foucault 1984). Heterotopias are marked by their difference from the dominant environment. Community gardens as heterotopias have already been discussed in the literature (Eizenberg, 2013), but not within the context of (post)socialist framework. Gardens are a type of space transformation that creates an urban heterotopia, an urban "alternative space", which at the same time encompasses and inverts the pre-existing relationships and property. In relation to the urban environment this almost rural activity seems unsuitable; in relation to the vibrant and dramatic urban life such country-side atmosphere in the middle of the city is unusually idyllic (Gulin Zrnić 2015). These old community gardens represented a deviation from the surrounding material urban space, and also from society's dominant socio-economic paradigm. The gardens stood in contrast to the newly constructed buildings in the middle of the urban landscape, with gardening viewed as a rural practice which does not belong inside the city and does not conform to the socialist ideal of the working class. The gardeners progressively took over the available green areas, most often in the immediate surroundings of their buildings. This was mostly land that was not in use and was waiting to be assigned a purpose (in stark contrast, for example, to the gardens in New York which sprung up during the 1970s primarily on abandoned plots of land in deprived parts of the city (Eizenberg 2013). The land was taken over mostly through joint neighbourly actions involving the clearing out of overgrown grass, shrubberies, or garbage. As new tenants moved in, more unused land around buildings was taken over and tailored into gardens accordingly (usually with built sheds or cottages). The allotment garden model did not exist so people were free to seize the land according to their own desires, needs and abilities.

The findings from Zagreb differ considerably from situations in some other former socialist countries, for example Poland, where perception and status of urban gardens was completely different. Poland also went through the same process of converting peasants into industrial workers, but in Poland access to a garden was considered a worker's right and in some respects even a duty (Bellows 2004). In accordance with this, the gardens were strictly organized by the authorities that had decision making freedom over all workers' gardens, including the development of membership rules, land use guidelines, and the distribution of allotment space (Bellows 2004). Unlike Zagreb, where gardens sprouted mostly in the immediate proximity of apartment buildings, the allotment gardens in Poland could be found adjacent to factories, rail lines, or school grounds. Zagreb's gardens were not similar to Soviet (and 
post-soviet) allotment gardens either, e.g. dachas, which were (are) located mostly in peri-urban areas, $10-100 \mathrm{~km}$ from the cities (Moldakov 2000). Dachas were administered by party-state leadership which strictly regulated land use (e.g. plot dimensions, living space, rooflines), and for the people queuing to get them they were important as an economic utility and status asset (Zavisca 2003). Urban agriculture in Russia had constant attention from public authority and thus more than 400 laws, decrees and regulations were issued between 1940 and 1990 (Boukharaeva and Marloie 2015).

On the other hand, these old gardens in Zagreb were illegally taken, created and maintained as gardeners' private worlds in which the state did not interfere. Considering the fact that the land gardeners had occupied throughout the city was not theirs, there was a need to send a clear message that it now belonged to somebody. This was addressed through the physical layout of the gardens. Most of the old gardens are comprised of a labyrinth of green hedges and fences separating individual plots (Fig 1). Communal property was an ideological pillar of socialist society, from the buildings the people lived in to the factories they worked in. The gardens were perceived by the gardeners as private, non-communal spaces and can also be seen as a heterotopia in the sense of ownership, a deviation from the dominant paradigm of a system which glorified communal property. It is important to note that the practice of organizing communal plots for cultivation was non-existent. Each plot was cultivated individually, and every gardener tended to his own plot exclusively. Every-day life situations have taught people very well how communal property, the property of everyone and no one, was managed and treated (abused). "Tragedy of the commons" was a familiar concept within that social order. The gardens were thus a type of private property, in spite of the fact that those gardens never actually belonged to the gardeners, and that society itself only partially recognized the concept of private property. 


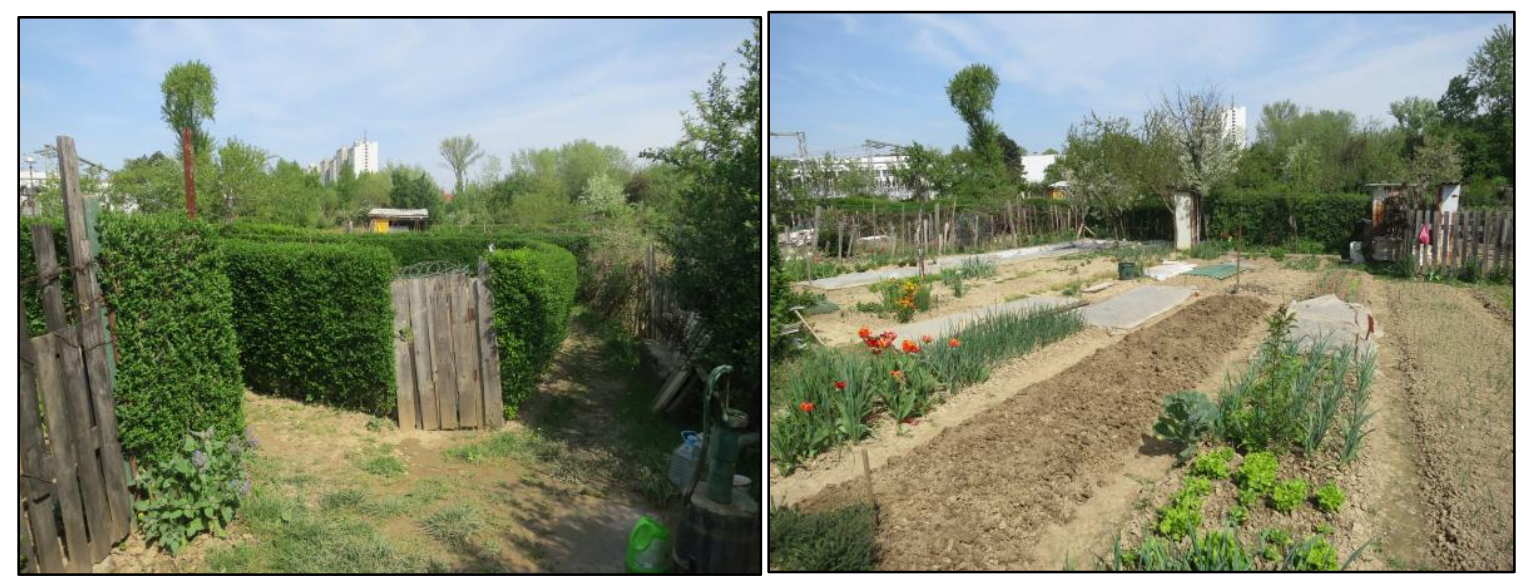

Fig. 1. An example of old (illegal) gardens in the city of Zagreb (photo: Lana Slavuj Borčić, 2015)

Despite the individual approach in cultivating their gardens, and the fences between the plots, lively communities have developed in the old gardens. Most gardeners have known each other for years, often dating from the times they jointly occupied and fenced off their plots of land. Baker (2004) states that gardens are good examples of how natural environment is intricately intertwined with the social environment. Gardeners through their gardening activity are producing space and culture through their construction of place. One gardener stated: "See this table here? We sit here, someone brings coffee, food, real peasant food...This has become our life I tell you. We have lunch here, eat, drink. Socialize. We do not visit each other's homes anymore to have coffee - all our free time is spent here. We are here every day, every day". The garden is a place where they're going back to their roots, where a part of their non-urban identity is freely expressed within an urban context: "This is how I was raised. This is what I do."

Therefore, the reasons for keeping the garden are mostly connected with the continuation of a family tradition of gardening as well as with quality and flavour of the home-grown food produced without the use of chemicals (mainly for home consumption). The old gardeners invested a lot of time, effort and love into these spaces, resulting in lasting memories and strong ties to their gardens, but also for fear of losing the land. One old gardener mentions: "We know it's not ours, but I consider it my land until someone takes it away from me. It means a lot for our lives, for our health. Tell them we would miss it a lot if they take it away from us. I am sure that time will come but, fortunately, the state is strapped for funds so hopefully it will not happen soon." This fear of losing the land is present 
among all the gardeners, with many stating that they would look for new places to tend their gardens if they are driven from their present gardens.

Despite the positive characteristics attributed to the old gardens by the gardeners, in relation to the cultural and economic framework within which the old, illegal gardens emerged, the perception of such gardens and gardeners by the remainder of the populace is reported as mostly negative. As mentioned earlier, the old gardens appeared in the wake of industrialization, during the socialist period when the value of industry was placed higher than the value of agriculture. Agriculture was considered a relic of the past, and the old gardeners were likewise perceived as relics of those times, as people who refused to embrace progress and allow themselves to be modernized: "There were negative comments, people used to tell me that's the reason why they left their home, so that they wouldn't have to work on the land and till with a hoe. I don't know. I tried not to pay attention." A part of the negative perception of the gardens comes from their illegal character. One gardener said: "People did not appreciate our efforts. They would say that the gardens are not ours and that when the harvest comes they'll just come in and pick everything. I know it's not mine, but it looks nicer, doesn't it? Because if it was left as it was, a bush, I'm not sure who could clean it anymore. But we each took a corner for ourselves and we cultivate them."

In a way, these old gardens of socialist period can be seen as a spontaneous manifestation of an unfinished socialist effort to transform a deeply rural society into a modern, urban, industry-based one. Spatially and materially they manifest themselves particularly in the places where this effort remained visually unfinished - land plots planned for the construction of large apartment blocks, bridges or major roads which were designed on paper but never built. Their cultivators, the gardeners of rural origin, represent a consequence of this experiment, people that Mišina (2013) calls a hybridized class of "urban bodies with rural souls" whose socio-economic identity is urban, but whose socio-cultural identity is still deeply rural. Most of the gardeners in this research were of the older generation, whose children live in different parts of Croatia often with different socio- economic backgrounds and no desire to continue the gardening tradition. Some of the plots in the illegal gardens we visited were already abandoned, even though the larger part was (is) still continually cultivated by ageing gardeners. Croatia entered its economic transition during an armed conflict which lasted for a better part of a decade, which, together with certain issues such as unresolved land ownership has resulted in a delayed processes of large-scale construction on previously unused land plots (Slavuj et al., 2009). Therefore the problems of contested private/public spaces in the city of Zagreb 
connected to the development of a neoliberal city emerged relatively later in comparison to other post-socialist cities in Eastern Europe (Lukić and Jakovčić 2004).

\section{Creating New Community Gardens in Post-Socialist Zagreb - Citizens' and Institutional Perspective}

In 1991, after the collapse of the communist and socialist system in Yugoslavia, Croatia decided to transform its economy according to free market-based principles, creating deep economic, political, cultural, and social changes. This period of economic transition also resulted in complex social, functional and morphological transformations which have left their mark in the urban structure of Zagreb. The "champions" of these transformations are new social actors, primarily economic (e.g. property investors) (Svirčić Gotovac and Zlatar 2015; Svirčić Gotovac and Zlatar 2008; Čaldarović 2011; Hodžić 2005) and political actors (Svirčić Gotovac and Zlatar 2015). By focusing on short-term economic benefits for their own interest, the new economic actors, supported by political actors, have become some of the most important figures in processes of gentrification and urban revitalization of Zagreb's city center in recent years. Numerous new commercial and mixed use business developments have appeared in the old urban core of Zagreb, waging and often winning battles for public space, and more often than not neglecting historical context.

As documented in the research about one of the most symbolic and emblematic city squares in Zagreb - the Flower Square (Svirčić Gotovac and Zlatar 2008), the building of yet another multifunctional shopping mall enabled by political support for private investors in 2011, resulted in the partial loss of public space in a pedestrian area sacrificed to accomodate an entrance to an underground garage. Another centrally located shopping center CascadePrebendarski vrtovi, which opened in 2009 and closed down in 2011, became a symbol of loss of valuable space in the battle with unsuccessful economic operations for private interests. Erosion of public spaces as a consequence of neoliberal privatization of public goods and services (Harvey 2007) is clearly taking place in Zagreb (Slavuj et al. 2009). Loss of public space in the city center was an alarm that woke up numerous citizens. More and more NGOs requested active participation in the local-decision making process and areas further away from immediate economic interest of powerful actors became the new battlefield. After the "Flower Square" case which alarmed the civil sector, as well as the broader community, citizens became more sensitive not only to the loss of public space, but also to their inability 
to participate in decision making process regarding their city. Garden-connected activism can also be interpreted as an answer of sorts to these processes and situations.

In spring of 2012, a small group of (mostly younger) citizens decided to plant a small community garden in the Travno neighbourhood of Zagreb. The selected location was an old community garden from the socialist era which was half-abandoned, but still used by some of the residents of the surrounding high-rises. Soon after the revitalization of several plots in the garden, City officials decided to remove all of the gardens in order to build a park. This caused an uproar in which a spontaneous citizens' action backed by several NGOs resulted in the adoption of a city-wide policy on urban gardening. It was the first time in recent history of Zagreb that a citizens' action in response to something that was seen as inadequate city management resulted in changes in city policy.

In this case, a group of citizens demanded more participation in the process of local decision-making: "Some of us Green Action activists started exploring. We decided to find out how this came to happen and this was the initial gathering of the Parkticipation. It is the idea that the people are never really consulted about anything, like what is the purpose of a public space and what should be done with it. What is the point of destroying useful greenery and replacing it with something purely decorative, without ever wondering about the true needs of the local populace? And the gardens are obviously such a need, since they've been there for years. Parks and other content are OK, but why not some sort of edible urban culture as well? And anyway, it was quite obvious that the park would not be happening any time soon ".

A few months later a similar event occurred in the Savica area of Zagreb where a construction development was supposed to take place on the location of an existing old garden. City officials started with small-scale preparatory construction works only to be faced with resistance from local gardeners: "They even came with bulldozers. When [the bulldozer] came, I was in the garden, I remembered our soldiers from the war and the barricades, I started crying and the driver turned off the engine and stopped with the demolition. Afterwards we wrote a petition, we will fight! We realized that you can't achieve anything if you keep quiet. Now we have temporary contracts, but they expire in December. Why December? Because it's winter, there are no plants during that period and the gardens will supposedly be empty when [the bulldozers] finally come."

This citizen's uproar in defense of their rights is exactly what Eizenberg (2013) describes as a reaction to social and environmental injustice inflicted by the progression of neoliberalization of urban space in the example of NY community gardens. In the process of attempting to protect these contested spaces, residents evolved into community leaders and 
urban activists. In case of community gardens in Zagreb, a new citizens' initiative called Parkticipacija (Parkticipation) emerged consisting of, among others, citizens who have been planting gardens in Travno in 2012. The initiative tackled the issues of community gardens and food production in the city: "We registered the organization in case we would have to manage a location or if a contract with the City would need to be signed, to make sure there is a legal framework in place. But at the beginning it was just an initiative, something like citizens' conscience."

The participants in this story describe themselves as young, urban and "without second homes or land inside or outside the city", completely without rural background or agricultural experience, juxtaposed with the old gardens and their gardeners, as well as the political and cultural framework of the previous regime. One of the activists, credited with starting up the first initiatives which founded the community gardens, told us how a sudden revelation about the magnitude of unused spaces within the city limits had encouraged her to try and change something: "I recognized that we, as citizens, would feel like part of the city if we were allowed to use the city's spaces. If you live in a building you have no real rights over the spaces outside your building. And it seems to me that through the gardens and the land that we have the right to use, we are finally becoming citizens of Zagreb, and not just random figures using public transportation, sleeping and moving on." This comment clearly verbalizes the need of the people to "inhabit" the city, and not only to "live" in the city, a need of the citizens to be active co-creators of the public space, and not just passive consumers (Lefebvre 1996).

After months of media campaigning and meetings with different Departments/Offices, City officials finally decided to implement the "Urban Gardens" policy in its programme. The first official community gardens were opened in 2013 in Zagreb in the neighbourhoods Klara and Sopot. A part of the study regarding possible locations was done with the help of "Parkticipacija" and other NGOs, but in the later stages they were not included in the project as it was taken over completely by the local authorities and local politics, to the extent that every contract for a plot of land had to be signed personally by the mayor. According to the "Urban Gardens" regulations, the community gardens are to be used by citizens of Zagreb exclusively for the production of food (vegetables and fruits), herbs and flowers for personal use and consumption. From the citizens' perspective, the most important aspect relates to the requirements for becoming a tenant of the community gardens. That procedure is implemented through a periodical open call to all persons living in the City of Zagreb who neither own nor 
currently use other pieces of arable land. The criteria used to manage the list of potential tenants includes: time spent residing in Zagreb; residence in the same city district as the "Urban Garden" plot; average monthly household income per family member; social care benefits and unemployment; Homeland $\mathrm{War}^{1}$ veteran status; retirement status; and number of members in the household. The successful applicant signs a two year contract detailing his rights and obligations, (which can be extended depending on proper use of the garden) which are internally administrated. The 50sqm plots are leased free of charge by the city and cultivated individually by the temporal owners. The gardeners share water, tools, and communal areas equipped with tables and benches. In the first year of the project, nine open calls resulted in 655 signed contracts, $50 \%$ of which were families with children, $20 \%$ Homeland War $^{1}$ veterans, $20 \%$ retired persons and $10 \%$ unemployed people. A total of six community gardens with 633 plots covering approximately 9.3 hectares were formed. During the last year, the number grew to ten community gardens, encompassing more than 2000 plots and 21 hectares respectively. The demand from citizens is still present, especially in the city districts where gardens do not exist. However, due to the financial constraints and difficulties in finding new suitable locations, the process might slow down in the future.

\section{Experiences in the New Community Gardens - A Space for My Own}

Unlike the old gardens which spread spontaneously on unused land according to the need and will of the gardeners, new ones are organized and planned places which, one could argue, sets them apart from the post-socialist city they are part of, a city where urban management is usually characterized by a retreat from planning, lack of institutional coordination, insufficient financing, and poor implementation of laws and regulations etc. (Stanilov 2007). The socio-economic and socio-cultural backgrounds of the new gardeners are diverse, but urban gardening as a continuation of tradition was never mentioned by the interviewees as a motive to take up gardening. The majority of the new gardeners had no previous experience working the land, as most of them are second or third generation city dwellers without close contacts or ties to the countryside. They started gardening with little prior knowledge, and some even attended gardening and permaculture classes. They are largely unfamiliar with tilling and appropriate sowing times, and often can't tell which plant is

\footnotetext{
${ }^{1}$ An armed conflict in Croatia from 1991 to 1995
} 
which. The gardens are only a year or two old, and this is seen as an experimental learning period; the new gardeners state that they regularly browse the Internet in search for useful information, read books on organic gardening or consult the gardening manual prepared by the City Office for Agriculture and Forestry (to help the inexperienced gardeners); knowledge is also being exchanged in the gardens themselves, people are learning directly from one another.

This approach is visibly different from the approach in the old gardens. The old gardeners gained their know-how many years ago, in their childhood, when they were obligated to help out doing hard work on their family properties in rural areas. The cultivation of land was not a pastime in those days, rather a matter of survival. This period, which they often recall with nostalgia, instilled in them a certain respect toward the land, an attitude that the land must be worked, and not left untended. Such ideas were embroidered into their gardens within urban surroundings. The new gardeners are different, they have yet to discover that connection, and they emphasize that this represents their return to nature, from which they feel alienated and wish to get to know better. "We spend more and more time on the computer and that is why this return to the land and working with your hands feels very good. High technology makes us more and more alienated from each other and nature. We, as a civilization, pollute a lot and I don't want to pollute. Because of our alienation, we experience nature as a resource that can be used, instead of experiencing it as a home we are part of." One of the most important and frequently mentioned reasons of having one's own garden is production of safe organic food produced without pesticides and herbicides. One young father told us bitterly: "I can't believe the stuff they're selling in supermarkets, I read the other day that they found all kinds of things in children's cereal boxes, apparently one in three [of them] is poisonous. The same is said about meat... wherever you turn you have no idea what you're putting in yourself. We don't want to put chemicals on our food." The mistrust of produce sold in supermarkets is considerable and gardeners often inquire about the origin of the food they consume, showing their feelings of alienation from food production processes and their worries regarding the function of the industrial agri-food system.

Unlike the old gardens which were perceived as primitive rural manifestations, intruders within the urban setting, the perception of the new gardens is different and mostly positive. While gardening and agriculture were seen as backwards in the socialist society, the new trends in environmentally friendly organic food production as well as the romantic notion of returning to nature are things that are appreciated and supported as parts of a modern, desirable lifestyle. As one gardener said: "It wasn't 
really anything serious when I took it up, but now it's completely different, people keep asking me if there is any more room, that they'd like to try too, where, what, how did you get to it... things like that. This means people are interested."

Just like with the old gardens, the new gardeners are aware of the possibility of losing their gardens. They know that construction and profit come before their personal satisfaction, that the land they are working on is "theirs" until the moment it is repurposed. The contracts for new city community gardens are signed for a two-year period with the possibility of renewal solely at the discretion of the City of Zagreb. The fact that the new community gardens are not mentioned in any of the long-term or medium-term city policies also makes for uncertainty. In spite of the temporary arrangement, the gardeners nonetheless establish a bond with their gardens. For the gardeners they are places of refuge in the city, or even a second home. One gardener told us: "It is like my second apartment. I clean it, I decorate it, the same thing you do with your apartment. Sometimes I spend the whole day here instead of indoors."

It is interesting to mention that none of the people we interviewed in the old or the new gardens mentioned financial reasons as their primary motive for owning a garden. It means that this is not about people not being able to afford food, or that the alternative to the gardening would be hunger. Comments about the gardens helping supplement low pensions were mentioned as one of the benefits of owning the garden but were always preceded by the importance of safe and tasty food, recreation, socializing, therapeutic aspects, and education. Some people even mentioned that not only do they not benefit financially from the gardens, but that they are actually a financial net loss (the cost of organic fertilizer, seeds, tools). One gardener told us: "None of us do it to survive. Doing work that you don't really have to do is the sweetest work of all." Furthermore, fresh food is readily available in Zagreb, almost all neighbourhoods have a wide selection of supermarkets, smaller stores and open-air markets. This is a significant difference from cities in North America or the UK where the problem of food deserts has surfaced, i.e. the unavailability of fresh produce primarily in deprived areas of cities (Crossney and Shellenberger 2012; Tangtrakul 2010; USDA 2009; Shaw 2014; Cummins and Macintyre 2006). One legacy of the socialist period is that the socioeconomic segregation in Zagreb is still not strongly expressed (Prelogović 2009); in that sense, the gardens cannot be spatially connected to individually deprived neighbourhoods as is the case in some other countries (Crossney and Shellenberger 2012; Eizenberg 2013; Ghose and Pettygrove 2014). On the contrary, the community gardens are 
present in almost all parts of Zagreb (Fig. 2).

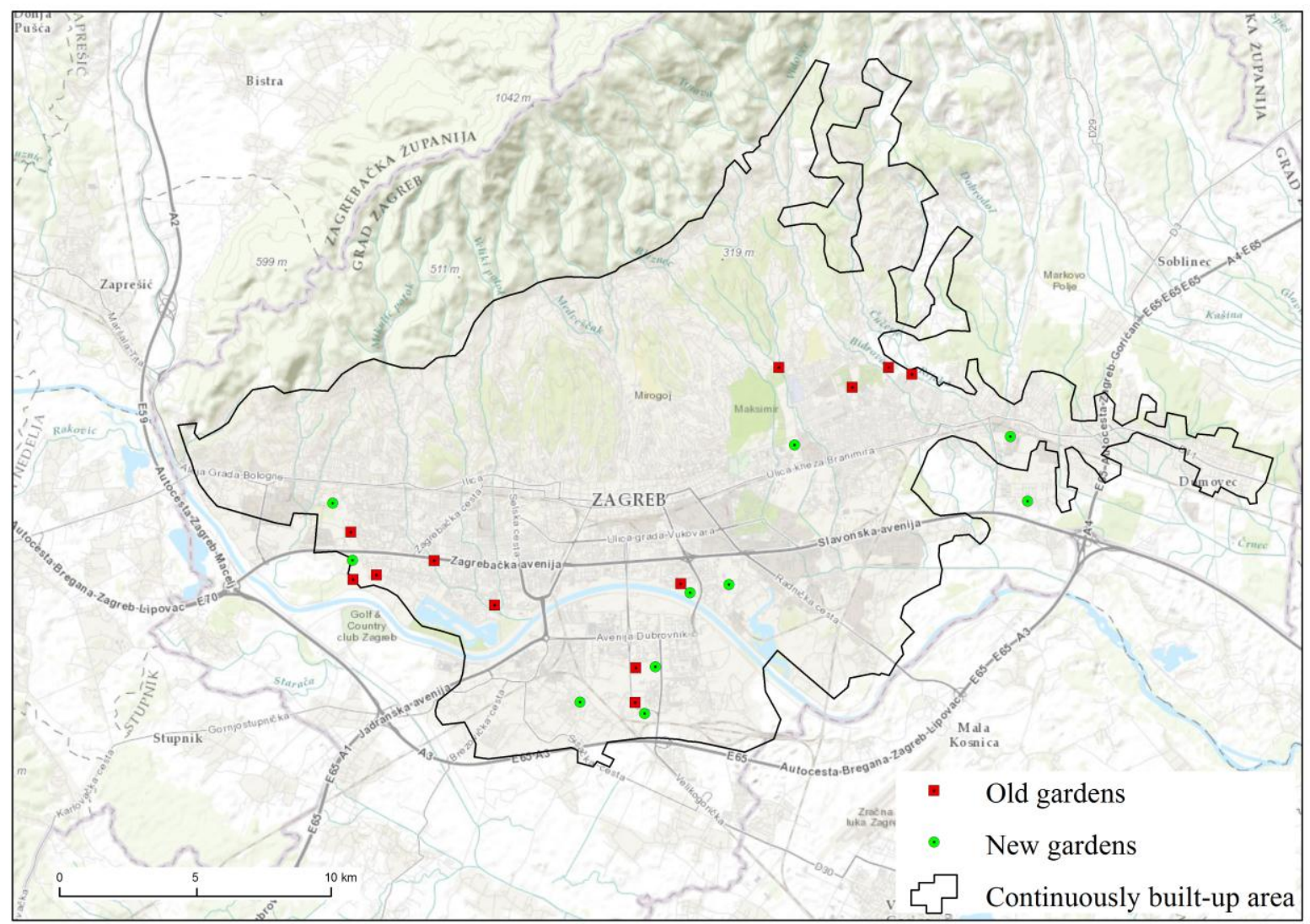

Fig. 2. The location of 10 community gardens established by the "Urban Gardens" project by 2015 and a number of old (illegal) gardens in the city of Zagreb in $2014^{2}$

These new gardens can also be seen as alternative spaces, heterotopias, only now within the post-socialist city. During the socialist period, in a time favoring communal property and industry, they were perceived as private spaces where rural practices occurred. Within a neoliberal society favouring the private and individual, the community gardens have become shared spaces with the freedom to create a place according to the wishes and needs that are not dominantly consumer oriented. They represent a negation of the dominant logic and practice in their emphasis on the use value of space rather than its exchange value (Eizenberg 2013). The values that socialist society tried to distance itself from are now back in focus, and the concept of common goods becomes something desirable again. Such a twist demanded a complete reinterpretation of the gardens in line with the reinterpretation of the social and economic paradigm, in both visual and conceptual terms. The new community gardens are therefore open places,

\footnotetext{
${ }^{2}$ Not all old (illegal) gardens are mapped here because of their illegal character and therefore unknown locations. The old gardens depicted in this figure were mapped during an extensive fieldwork in 2014.
} 
without physical barriers (Fig 3). They are planned as areas for socializing and spending free time, a compensation of sorts for the loss of public space undergone in the city of Zagreb in recent years (Svirčić Gotovac and Zlatar 2008).

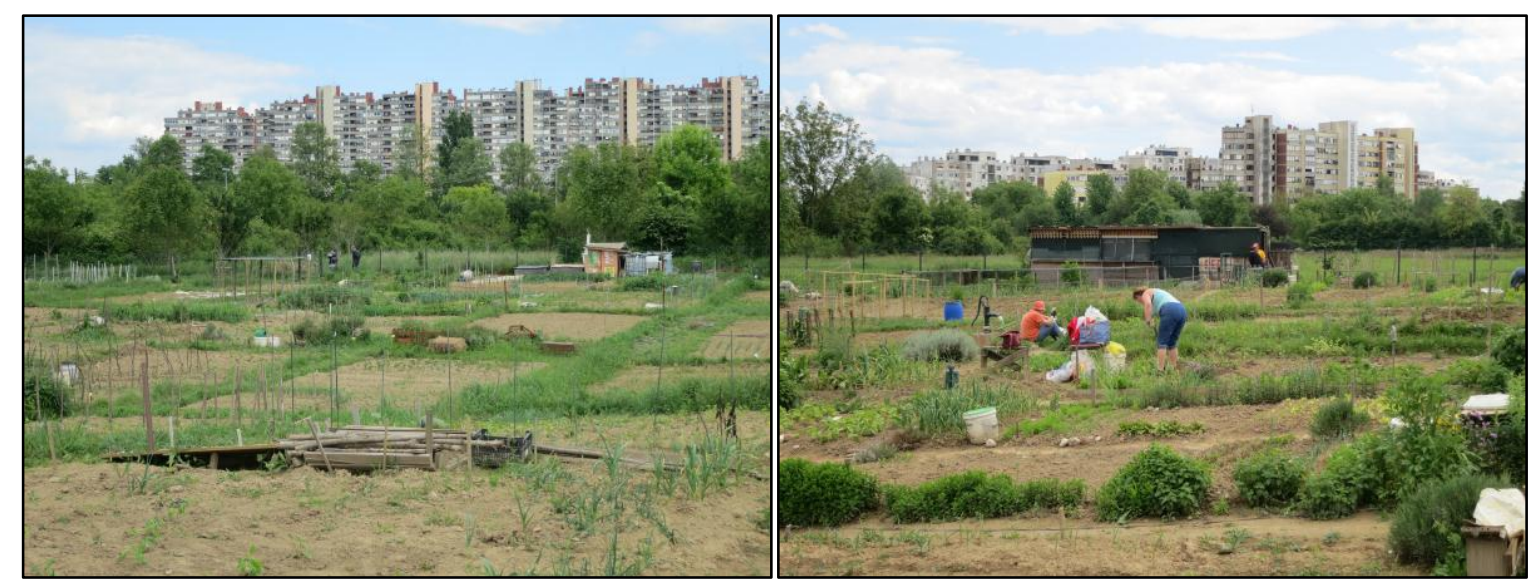

Fig. 3. An example of new gardens established by the "Urban Gardens" project in the Sopot area (photo by Lana Slavuj Borčić, 2015)

\section{Conclusion}

Community gardens in Zagreb are dynamic multilayered spaces whose meaning has changed with changes of political regimes. What they have in common in both examined periods is that they represent places of organic food production, socialization, recreation, places for enjoying nature as well as low income supplementation. The thing that has changed during the post-socialist transition in (former) Yugoslavia is the gardens' relation to the dominant social and political paradigm within which they emerged. In both periods they stand in opposition with this paradigm, and can thus be read as urban heterotopias.

In the socialist period the agriculture was not supposed to exist in the urban environments of Yugoslavian cities - small scale agriculture was seen as backwards and anything apart from the new industrial development was deemed as undesirable. During the 1950s Yugoslavia was still deeply rural and together with Albania it was economically the most backward country of Europe, having not even undergone an industrial revolution. Therefore such radical renouncing of the rural should not come as a surprise. In the period between 1950 and 1970 GDP growth was on average about $10 \%$, which was at the time one of the largest industrial growth rates in the world (Siebel and Damachi 1982). In such circumstances there was no place for traditional, small scale agriculture, especially in urban 
areas.

The attitude of authority is well seen in the absence of any official attempt or rule considering the acquisition of the urban land for the food production in the city. But as the new citizens were people of rural origin, their traditional lifestyles soon started to manifest in the urban landscape. Their gardens stood in strong opposition to both the ideological and the material city. They were secluded, private, pseudo-rural places in a semi authoritarian, communal, and (supposedly) urban and industrial society. In post-socialist Zagreb, characterized by an uncontrolled and unplanned spatial context heavily relying on neoliberal market-oriented principles, social insensitivity and exclusion, the new gardens are often depicted as beacons of communal involvement, grassroots movements, and the ability of citizens to stand together and make their voices heard. While gardeners in the old gardens clearly represent a homogeneous segment of society which was socially and ideologically seen as inferior - a rural element in an urban environment - the new gardeners reflect the pluralism of a neoliberal society. Accordingly, the City's „Urban Gardens” program includes the winners and losers of the process of privatization of public goods and spaces, war veterans, lower income families, people seeking a rural experience that they never had, and those looking for their own little green oasis in the concrete desert, reflecting the heterogeneity of neoliberal processes, particularly in their production of divergent social inequalities across urban space (Pedroni 2011).

Many of the old gardens are on plots where there are plans to build roads, apartment buildings or other structures, and they will remain there until a different, "better" purpose is found. They are referred to as "illegal", "wild" or "guerilla" in media, and "Urban Gardens" in project documentation, and seen as marginal spaces the City has no need of at present, but may freely take possession of if deemed necessary. Conversely, the new gardens are the response of a handful of local enthusiasts who decided to fight for their right to the city's public spaces and the new vision of local authorities regarding the use of public spaces.

An important issue in discussion about community gardens in Zagreb, both old and new, is the fact that they don't exist in any of the official planning documents. The category of "urban garden" is unknown under the national spatial planning regulatory framework. They are non-permanent structures which owe their existence to the fact that local governments have been able to find case-by-case exceptions from the planning law. In a way, their existence is acknowledged and temporarily regulated, until development plans designated for those areas are put in motion. Different initiatives, NGO's, and citizens are 
trying to find their way through this lack of legal framework, a framework which is crucial for a long-term solution of this problem. It is almost absurd that even the new gardens, placed under the auspices of the City Government and financed by the City budget, are only a temporary project with uncertain future, despite the positive experience of the citizens and an enormous effort put into their management and organization. Though the status of the new gardens is just a tiny bit more certain than that of the old; both the old and new gardeners fear for the future of their little sanctuaries.

However, seeing as the old gardens have been around for so long, and the new ones represent semi-official versions of those practices which are gaining momentum, the need for their presence in society is clear and demonstrates that legislative changes are in order. The old urban gardens are being rediscovered as oases of pseudo-rural areas of sorts in the symbolic sense of closer social ties, closeness to nature, other people and self within the context of an aimless and poorly directed urbanization process burdened by privatization and instrumentalization of public spaces, especially in the centre of Zagreb. The new gardens can, in the same manner, be interpreted as the counterpart to the negative elements of the dominance of investors over spatial planning. They are a vision of a more humane post-socialist society with unavoidable neoliberal elements, mirroring itself in these new green communal oases. For all these reasons, these gardens should be upgraded from their status of marginal, wasted or "waiting" places to more important places on the city map, which properly reflects their importance both to the gardeners and to the city itself. The inclusion of the concept of community gardens in spatial planning documentation and its positioning as a permanent category is the next step the authorities should make. This would show that local policy has finally recognized and accepted urban agriculture as a worthy and respectable element of the urban environment, not as intruder to urban city space. 


\section{REFERENCES}

Alaimo K, Reischl T M and Allen J O (2010) Community gardening, neighborhood meetings, and social capital. Journal of Community Psychology 38(4):497-514

Armstrong D (2000) A survey of community gardens in upstate New York: Implications for health promotion and community development. Health \& Place 6(4):319-327

Ashebir D, Pasquini M and Bihon W (2007) Urban agriculture in Mekelle, Tigray state, Ethiopia: Principal characteristics, opportunities and constraints for further research and development. Cities 24(3):218-228

Baker L E (2004) Tending Cultural Landscapes and Food Citizenship in Toronto's Community Gardens. Geographical Review 94(3):305-325

Bellows A C (2004) One Hundred Years of Allotment Gardens in Poland. Food and Food ways 12(4):247-276

Boukharaeva L M and Marloie M (2015) Family urban agriculture in Russia: Lessons and prospects. New York:Springer

Crossney K B and Shellenberger E (2012) Urban food access and the potential of community gardens. Middle States Geographer 44:74-81

Cummins S and Macintyre S (2006) Food environments and obesity—neighbourhood or nation? International Journal of Epidemiology 35(1):100-104

Čaldarović O (2011) Urban society at the beginning of the 21 st century. Zagreb: Jesenski i Turk

Dhakal S and Lilith M (2011) Exploring the viability of community-based sustainability initiatives in Perth with a lens of social capital. World Planning Schools Congress 2011. http://epubs.scu.edu.au/tourism_pubs/1997.

Drake L and Lawson L J (2014) Validating verdancy or vacancy? The relationship of community gardens and vacant lands in the U.S. Cities 40, Part B:133-142

Eizenberg E (2012a) Actually Existing Commons: Three Moments of Space of Community Gardens in New York City. Antipode 44(3):764-782

Eizenberg E (2012b) The Changing Meaning of Community Space: Two Models of NGO Management of Community Gardens in New York City. International Journal of Urban and Regional Research 36(1):106-120

Eizenberg E (2013) From the Ground Up: Community Gardens in New York City and the Politics of Spatial Transformation. Farnham, Surrey, England; Burlington,VT: Ashgate PubCo

Evers A and Hodgson N L (2011) Food choices and local food access among Perth's 
community gardeners. Local Environment 16(6):585-602

Ferris J, Norman C and Sempik J (2001) People, Land and Sustainability: Community Gardens and the Social Dimension of Sustainable Development. Social Policy \&Administration 35(5):559-568

Firth C, Maye D and Pearson D (2011) Developing “community” in community gardens. Local Environment 16(6):555-568

Follmann A and Viehoff V (2014) A green garden on red clay: creating a new urban common as a form of political gardening in Cologne, Germany. Local Environment 1-27

Foucault M (1984). Of Other Spaces: Utopias and Heterotopias. Architecture /Mouvement/ Continuité. http://www.google.hr/url?

$s a=t \& r c t=j \& q=\& e s r c=s \&$ source $=w e b \& c d=1 \& v e d=0 C B w Q F j A A \quad \& u r l=h t t p \% 3 A \% 2 F$

$\% 2 F$ web.mit.edu\% 2 Fallanmc\% $2 F w w w \% 2 F f o u c a u l t 1 . p d f \& e i=X f q D V c z n$

F4HksgHPoID4DA\&usg=AFQjCNGyuaZMuCRKdw_-

gZ2FuQOFo5idog \&bvm=bv.96042044,d.bGg.(last accessed 2 June 2015)

Ghose R and Pettygrove M (2014) Urban Community Gardens as Spaces of Citizenship. Antipode 46(4):1092-1112

Glover T D (2003) The Story of the Queen Anne Memorial Garden: Resisting a Dominant Cultural Narrative. Journal of Leisure Research 35(2):190-212

Glover T D (2004) Social capital in the lived experiences of community gardeners.

Leisure Sciences 26(2):1-20

Glover T D, Parry D C and Shinew K J (2005) Building Relationships, Accessing Resources: Mobilizing Social Capital in Community Garden Contexts. Journal of Leisure Research 37(4):450-474

Glover T D, Shinew K J and Parry D C (2005) Association, Sociability, and Civic Culture: The Democratic Effect of Community Gardening. Leisure Sciences 27(1):75-92

Gulin Zrnić V (2012) Gradski mali vrtovi - urbane heterotopije. Zarez 14(345):20

Gulin Zrnić V (2015) Vrtovi našeg grada: studije i zapisi o praksama urbanog vrtlarenja. Zagreb: Institut za etnologiju i folkloristiku Hrvatsko etnološko društvo Parkticipacija

Guthman J (2008) - If They Only Knew: Color Blindness and Universalism in California Alternative Food Institutions. The Professional Geographer 60(3):387-397

Hodžić A (2005) Social restructuring and new social context. Sociology of the Village 43, 169(3):497-525.

Harvey D (2007) A Brief History of Neoliberalism. Oxford: Oxford University Press

Holland L (2004) Diversity and connections in community gardens: a contribution to local sustainability. Local Environment 9(3):285-305 
Irvine S, Johnson L and Peters K (1999) Community gardens and sustainable land use planning: A case-study of the Alex Wilson community garden. Local Environment 4(1):33-46

Kingsley J Y and Townsend M (2006) "Dig in" to social capital : community gardens as mechanisms for growing urban social connectedness. Urban policy and research: an Australian and New Zealand guide to urban affairs 24(4):525-537

Kurtz H (2001) Differentiating Multiple Meanings of Garden and Community. Urban Geography 22(7):656-670

Lawson L (2007) Cultural geographies in practice The South Central Farm: dilemmas in practicing the public. Cultural Geographies 14(4):611-616

Lefebvre H (1996) Right to the city. In: Writings on cities (eds. Kofman E and Lebas E), Oxford:Blackwell. 63-264

Lukić A and Jakovčić M (2004) Location and function of hypermarkets and shopping centers in Zagreb. Dela 22:39-54

Maxwell D, Levin C and Csete J (1998) Does urban agriculture help prevent malnutrition? Evidence from Kampala. Food policy 23(4):411-424.

Meenar M and Hoover B (2012) Community Food Security via Urban Agriculture: Understanding People, Place, Economy, and Accessibility from a Food Justice Perspective. Journal of Agriculture, Food Systems, and Community Development 3(1):143-160

Mišina D (2013) Shake, Rattle and Roll: Yugoslav Rock Music and the Poetics of Social Critique. Ashgate Publishing Ltd, Surrey, England.

Moldakov O (2000) The urban farmers of St Petersburg. Resource Centre on Urban Agriculture and Food Security (RUAF)

http://www.ruaf.org/sites/default/files/Urban\%20agriculture\%20in\%20St\%20Petersburg,\%20 Russia.pdf (last accessed 14 June 2015)

Moyo P (2013) Urban Agriculture and Poverty Mitigation in Zimbabwe: Prospects and Obstacles in Bulawayo Townships. J Hum Ecol 42(2):125-133

Musil J (2005) City development in Central and Eastern Europe before 1990: Historical context and socialist legacies. In: Transformation of cities in central and Eastern Europe (ed. Hamilton I, Dimitrovska Andrews K and Pichler-Milanović N), United Nations University Press: Tokyo, 22-43

Pedroni T C (2011) Urban shrinkage as a performance of whiteness: neoliberal urban restructuring, education, and racial containment in the post-industrial, global niche city. Discourse: Studies in the Cultural Politics of Education 32 (2):203-215

Pleskovic, B (1988) Squatter housing in Yugoslavia. In: Spontaneous Shelter: International Perspectives and Prospects (ed. Patton C V), Temple University Press: Philadelphia, 277-302

Prelogović V (2009) Primjena faktorske analize u istraživanju socio-prostorne strukture 
grada: primjer Zagreba. Hrvatski geografski glasnik 71(1): 67-85.

Reynolds K (2014) Disparity Despite Diversity: Social Injustice in New York City's Urban Agriculture System. Antipode 00(0):1-20

Rihtman-Auguštin D (1988) Etnologija naše svakodnevice. Zagreb: Školska knjiga

Rosol M (2012) Community Volunteering as Neoliberal Strategy? Green Space Production in Berlin. Antipode 44(1):239-257

Rosol M (2010) Public Participation in Post-Fordist Urban Green Space Governance: The Case of Community Gardens in Berlin. International Journal of Urban and Regional Research 34(3):548-563

Saldivar-Tanaka L and Krasny M E (2004) Culturing community development, neighborhood open space, and civic agriculture: The case of Latino community gardens in New York City. Agriculture and Human Values 21(4):399-412

Schmelzkopf K (1995) Urban Community Gardens as Contested Space. Geographical Review 85(3):364-382

Schmelzkopf K (2002) Incommensurability, Land Use, and the Right to Space: Community Gardens in New York City. Urban Geography 23(4):323-343

Schukoske J E (2000) Community development through gardening: State and local policies transforming urban open spaces. New York University Journal of Legislation and Public Policy 3(2):351-392

Seferagić D (2006) The Pyramidal Network of Settlements in Croatia. Sociologija sela 44 3): 355-368.

Svirčić Gotovac A and Zlatar J (2015) Urban Processes in Zagreb. Residential and Commercial Developments. Hrvatski geografski glasnik 77(1):29 - 45

Svirčić Gotovac A and Zlatar J (2008) Akteri rekonstrukcije Cvjetnoga trga u Zagrebu. Sociologija i prostor 46(1):53-76

Shaw H J (2014) The Consuming Geographies of Food: Diet, Food Deserts and Obesity. Routledge

Siebel HD and Damachi UG (1982) Self-Management in Yugoslavia and the Developing World. Palgrave MacMillan

Simatele D M and Binns T (2008) Motivation and Marginalization in African Urban Agriculture: The Case of Lusaka, Zambia. Urban Forum 19(1):1-21

Slavuj L, Cvitanović M and Prelogović V (2009) Emergence of problem areas in the urban strucuture of post-socialist Zagreb. Spatium 21: 76-83.

Slocum R (2006) Anti-racist Practice and the Work of Community Food Organizations. 
Antipode 38(2):327-349

Slocum R (2007) Whiteness, space and alternative food practice. Geoforum 38(3):520-533

Smith C M and Kurtz H E (2003) Community Gardens and Politics of Scale in New York City. Geographical Review 93(2):193-212

Staeheli LA, Mitchell D and Gibson K (2002) Conflicting rights to the city in New York's community gardens. GeoJournal 58(2-3):197-205

Stanilov K (2007) Taking stock of post-socialist urban development: Arecapitulation. In: ThePost-Socialist City, Urban Form and Space Transformations in Central and Eastern Europe after Socialism (ed. Stanilov K ), Dordrecht: Springer

Stocker L and Barnett K (1998) The significance and praxis of community-based sustainability projects: Community gardens in western Australia. Local Environment 3(2):179-189

Tangtrakul K (2010) Food Accessibility and Food Choice: A Comparative Analysis of Food Choice in Developed and Developing Populations. Middle State Geographer 43:35-43

Turner B (2011) Embodied connections: sustainability, food systems and community gardens. Local Environment 16(6):509-522

USDA Economic Research Service - AP-036.http://www.ers.usda.gov/publications/apadministrative-publication/ap-036.aspx (last accessed 2 November 2014).

Wakefield S, Yeudall F, Taron C, Reynolds J and Skinner A (2007) Growing urban health: Community gardening in South-East Toronto. Health Promotion International 22(2):92- 101

Wekerle G R (2004) Food Justice Movements Policy, Planning, and Networks. Journal of Planning Education and Research 23(4):378-386

Zavisca J (2003) Contesting capitalism at the post-soviet dacha: The meaning of food cultivation for urban Russians. Slavic Review 62(4):786-810

Zezza A and Tasciotti L (2010) Urban agriculture, poverty, and food security: Empirical evidence from a sample of developing countries. Food Policy 35:265-273 